\title{
PERCEPTION OF HEALTH, OBESITY RISK AND DIETARY HABITS IN YOUTH
}

\section{PERCEPCJA ZDROWIA, ŚWIADOMOŚĆ RYZYKA OTYŁOŚCI I NAWYKI ŻYWIENIOWE U MŁODZIEŻY}

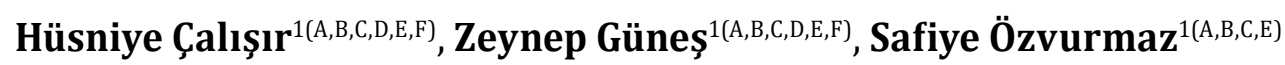

\author{
${ }^{1}$ Aydın Adnan Menderes University, Aydın, Turkey
}

Authors' contribution Wkład autorów: A. Study design/planning zaplanowanie badań B. Data collection/entry zebranie danych C. Data analysis/statistics dane - analiza i statystyki D. Data interpretation interpretacja danych E. Preparation of manuscript przygotowanie artykułu F. Literature analysis/search wyszukiwanie i analiza literatury G. Funds collection zebranie funduszy
Tables: 3

Figures: 0

References: 30

Submitted: 2018 Jun 19

Accepted: 2018 Jul 16

\section{Summary}

Background. The aim of this study was to determine the relationship between eating behaviour, health perception and obesity risk awareness in adolescents.

Material and methods. This cross-sectional study was completed with 579 adolescents. Stratified and simple random sampling methods were used in the selection of the high schools, classes and students. The data was collected through the information form, Dutch Eating Behaviour Questionnaire and Perception of Health Scale.

Results. The mean score of health perception of the adolescents was $52.34 \pm 7.59$. There was a positive relationship between total health perception score and emotional eating behaviour score of the adolescents $(\mathrm{p}=0.003)$. There was a negative relationship between total health perception score restricted eating behaviour $(p=0.029)$, and external eating behaviour score $(\mathrm{p}<0.001)$. The emotional eating behaviour $(\mathrm{p}=0.007)$, external eating behaviour $(\mathrm{p}=0.001)$ and total eating behaviour score $(p<0.001)$ of the adolescents who believed they had an obesity risk were found to be higher than the adolescents who believed they did not.

Conclusions. The adolescents with better health perception are less affected by the environment and are able to restrict their food choices. The adolescents who think that they have an obesity risk consume more food due to their emotional state and external exposure.

Keywords: obesity, adolescents, eating behaviour, health perception, risk awareness

\section{Streszczenie}

Wprowadzenie. Praca miała na celu określenie związku pomiędzy percepcją zdrowia, świadomością ryzyka otyłości a nawykami żywieniowymi u młodzieży.

Materiał i metody. To przekrojowe badanie zostało przeprowadzone wśród 579 nastolatków. W doborze szkół, klas i studentów wykorzystano próbę warstwową i proste losowe metody selekcji. Dane zebrano z wykorzystaniem formularza, kwestionariusza postrzegania zdrowia i holenderskiego kwestionariusza nawyków żywieniowych.

Wyniki. Średni wynik percepcji zdrowotnej uczestników w badanej grupie określono jako $52,34 \pm 7,59$. Istniała pozyty wna zależność pomiędzy całkowitą percepcją zdrowia uczestników a ich nawykami żywieniowymi $(\mathrm{p}=0,003)$, oraz negatywna zależność pomiędzy oceną ich ograniczonych nawyków żywieniowych $(\mathrm{p}=0,029)$ a zewnętrznymi nawykami żywieniowymi $(\mathrm{p}<0,001)$. Wyniki emocjonalnych nawyków żywieniowych osób, które uważają, że są zagrożone otyłością ( $p=0,007)$, ich wyniki zewnętrznych nawyków żywieniowych $(p=0,001)$ oraz zachowania $(\mathrm{p}=0,001)$ były wyższe niż u tych osób, które uważały, że nie są zagrożone otyłością.

Wnioski. Środowisko ma mniejszy wpływ na młodych ludzi, których charakteryzuje wyższy poziom percepcji zdrowia, a także którzy ograniczają swój wybór żywności. Z drugiej strony ci, którzy sądzą, że są zagrożeni otyłością, spożywają więcej pokarmu z powodu stanów emocjonalnych i wpływów zewnętrznych.

Słowa kluczowe: otyłość, młodzież, nawyki żywieniowe, percepcja zdrowia, świadomość ryzyka

Address for correspondence / Adres korespondencyjny: Hüsniye Çalışır, Aydın Adnan Menderes University, Nursing Faculty, Aytepe, 09010 Efeler/Aydın, Turkey, e-mail: hcalisir@adu.edu.tr, phone: +902562138866

ORCID: Hüsniye Çalıșır https://orcid.org/0000-0001-5440-5431, Zeynep Güneș https://orcid.org/0000-0001-6457-2137,

ORCID: Hüsniye Çalıșır https://orcid.org/0000-0001-5440-54
Safiye Özvurmaz https://orcid.org/0000-0002-1842-3058

Copyright: (C) Pope John Paul II State School of Higher Education in Biała Podlaska, Hüsniye Çalıșır, Zeynep Güneș, Safiye Özvurmaz. This is an Open Access journal, all articles are distributed under the terms of the Creative Commons Attribution-NonCommercial-ShareAlike 4.0 International (CC BY-NC-SA 4.0) License (http:// creativecommons.org/licenses/by-nc-sa/4.0/), allowing third parties to copy and redistribute the material in any medium or format and to remix, transform, and build upon the material, provided the original work is properly cited and states its license. 


\section{Introduction}

The obesity epidemic is one of the fastest growing threats all over the world. Overweight and obesity are conditions characterised by abnormal or excessive fat accumulation [1]. Childhood obesity is considered one of the most severe public health challenges of the $21^{\text {st }}$ century. Globally, around one in 10 young people aged 5-17 years are overweight or obese, with levels increasing rapidly in many countries and regions in recent years [2]. In Europe, fifteen-year-olds reported as overweight were 15\% (boys) and 9\% (girls) [3]. In a systematic review and meta-analysis by Maïano et al. (2016), the prevalence of overweight, overweight-obesity, and obesity in adolescents were 18\%,33\%, and 15\%, respectively [4]. Adolescent obesity is associated with obesity in adulthood [5]; it can also have long-term health implications $[3,6]$.

Genetic, endocrine conditions and lifestyle factors, which include physical inactivity and eating habits, are known as a cause of overweight or obesity among adolescents $[1,6]$. Unhealthy eating behaviours and physical inactivity among adolescents are common [6]. Among adolescents, the leading cause of overweight is wrong eating habits [6, 7]. There are individual differences in eating behaviour in adolescents. The factors affecting eating behaviour are the physical, developmental, and social changes that occur during adolescence [8]. Research related to adolescent obesity have focused on individual characteristics and the environmental influences on eating behaviours [7, 8]. One study reported that eating behaviours of adolescents are affected by cognitive mechanisms [9]. Khodabakhsh and Kiani (2014) stated: "anxious mood and emotions expression can influence eating behaviours" [10]. The emotional eating behaviour and external eating behaviour may play a significant role in the development of obesity [10,11]. The most important way to reduce obesity risk factors is awareness about causes and consequences of obesity, which are the keys to combating obesity $[12,13]$. Also, understanding obesity risk perception is essential when developing health strategies to combat this epidemic. Muturi et al. (2016) reported that awareness and risk perception are important in the behaviour change process [8]. The lifestyle and eating habits acquired at a young age translate into health in adulthood [14]. However, there is very little information literature on the awareness of obesity, its health risks and risk factors among adolescents. The purpose of this study was to determine the relationship between health perceptions, obesity risk awareness and eating behaviours in adolescents.

This study aimed to answer the following questions:

Does the perception of obesity risk affect eating behaviour in adolescents?

Does the awareness of obesity-related health problems affect eating behaviour in adolescents?

Is there a relationship between the health perception and eating behaviour in adolescents?

\section{Material and methods}

This cross-sectional study was conducted between September 2015 and June 2016 among adolescents studying in high schools located in the centre of a city situated in the west of Turkey. The study population were the adolescents $(\mathrm{N}=16,559)$ studying in 28 different high schools located in the city centre of Aydın province in the 2015-2016 school year. Stratified and simple random sampling methods were used in the selection of the sample. The high schools in the city centre were divided into two strata: vocational/technical high schools and general high schools. The students studying in the $1^{\text {st }}$ and $2^{\text {nd }}$ grade in 5 different high schools (two vocational/ technical high schools, two general high schools and one private high school) were selected by simple random sampling method considering the density of the high schools in the strata. The sample size, when the number of the individuals in the population of the study was known, was determined as at least 173 adolescents according to the proportion of overweight and obese children, taking the prevalence of adolescent obesity as $12 \%$ at $95 \%$ confidence interval and at the significance level of 0.05 . The adolescents who could speak and write Turkish and agreed to participate in the study and were allowed by their parents to participate in the study were included in the study. The study was completed with a total of 579 adolescents.

The data were collected using an information form, Dutch Eating Behaviour Questionnaire (DEBQ) and Perception of Health Scale. In addition, a standard weighing scale was used to measure the weight of the adolescents, and a tape measure was used for the height of the adolescents.

The information form contained information related to the socio-demographic characteristics of the students (age, gender, income level etc.), Body Mass Index (BMI) and the obesity risk.

The Dutch Eating Behaviour Questionnaire (DEBQ) consists of three sub-scales and 33 items evaluating the emotional eating behaviours (e.g. Do you eat dessert when you are sad?), external eating behaviours (e.g. If food smells and looks good, do you eat more than usual?), and restrained eating behaviours (e.g. 'Do you try to eat less at mealtimes than you would like to eat?). The items in the questionnaire are evaluated with 5-point Likert scale (1=never, $2=$ rarely, $3=$ sometimes, $4=$ often, $5=$ very often). Cronbach-alpha internal consistency coefficients 
of the original scale were found to be 0.95 for emotional eating behaviour, 0.81 for external eating behaviour and 0.95 for restrained eating behaviour $[15,16]$.

The Perception of Health Scale is a five-point Likert-type scale consisting of 15 items and four sub-factors (control centre, self-awareness, precision and importance of health). The lowest score that may be obtained from the scale is 15, and the highest score is 75 [17]. Cronbach's alpha reliability coefficient of the original scale is 0.90 for the control centre, 0.91 for self-awareness, 0.91 for precision and 0.82 for the importance of health. It was found in the Turkish validity and reliability study that while the test re-test reliability coefficient of the total scale was $\alpha=0.77$, reliability coefficients of the sub-scales were 0.76 for control centre, 0.63 for self-awareness, 0.71 for precision and 0.60 for the importance of health [18].

The researchers made an appointment with the school administration before reporting to the school on the appointed day. Explanations were given to the student group in the class determined by the simple random sampling method. The adolescents who agreed to participate in the study filled out the questionnaires by a selfreport method.

The study was conducted according to the guidelines laid down in the Declaration of Helsinki. Official permission was obtained from the institutional review board of Aydin Province National Education Directorate in order to conduct this study. All participants and their parents were informed about the study and gave verbal informed consent before the enrolment.

In determining the nutritional status of the adolescents, their body mass index (BMI, weight [kg]/height $\left[\mathrm{m}^{2}\right]$ ) were calculated from their weight and height measurement data, and percentile curves were used based on BMI. BMI percentiles for age and gender were calculated according to the 2008 standard growth charts for Turkish children [19]. In this study, overweight was defined as a BMI at or above the $85^{\text {th }}$ percentile and below the $95^{\text {th }}$ percentile for children and teens of the same age and sex. Obesity was defined as a BMI at or above the $95^{\text {th }}$ percentile for children and teens of the same age and sex [19]. Overweight and obese categories were combined, normal and underweight ones were shown separately.

Analyses were done using PASW Statistical Program version 22.0 (SPSS Inc, IBM, IL, USA). Data were represented as number, percentage or mean, standard deviation, where appropriate. The suitability of dependent variables (emotional eating behaviour, external eating behaviour, restrained eating behaviour, and perception of health scores) to normal distribution was tested using skewness and kurtosis values. Accordingly, all variables were accepted to have normal distribution since the skewness and the kurtosis values were between -1.00 and +1.00 . Student's t-test, One-way ANOVA and Turkey HSD tests were used for the comparison between independent variables and DEBQ score. The association between the perception of health and eating behaviour was analysed using Pearson correlations. The two-sided level of significance was set at $\mathrm{p}<0.05$.

\section{Results}

The mean BMI value was $20.43 \mathrm{~kg} / \mathrm{m}^{2}(\mathrm{SD}=3.20)$. It was determined that $56.5 \%(\mathrm{n}=327)$ of the adolescents were male, $80 \%(n=463)$ were in $9^{\text {th }}$ grade, $73.4 \%(n=425)$ had sufficient income level and $92.2 \%(n=534)$ did not smoke. Only $11.6 \%(n=67)$ of the participants were overweight or obese. However, 33.5\% (n=193) reported that they perceived themselves as overweight or obese (Table 1).

Table 1. Characteristics of participants $(\mathrm{N}=579)$

\begin{tabular}{|c|c|}
\hline Characteristics & Mean (SD) \\
\hline Age (yrs) & $15.24(0.59)$ \\
\hline Height (cm) & $169(9.03)$ \\
\hline Weight $(\mathrm{kg})$ & $59.17(12.03)$ \\
\hline BMI $\left(\mathrm{kg} / \mathrm{m}^{2}\right)$ & $20.43(3.20)$ \\
\hline & Number (\%) \\
\hline Sex & $252(43.5)$ \\
Female & $327(56.5)$ \\
Male & \\
Grade & $463(80.0)$ \\
$9^{\text {th }}$ grade & $116(20.0)$ \\
$10^{\text {th }}$ grade & $154(26.6)$ \\
\hline Unsatisfactory & $425(73.4)$ \\
\hline Satisfactory & \\
\hline
\end{tabular}




\begin{tabular}{|c|c|}
\hline Smoking & \\
Yes & $45(7.8)$ \\
No & $534(92.2)$ \\
\hline Weight status & $102(17.6)$ \\
Underweight & $410(70.8)$ \\
Normal & $67(11.6)$ \\
\hline Overweight or obese & $111(19.2)$ \\
\hline Perception of weight & $274(47.3)$ \\
Underweight & $193(33.5)$ \\
\hline
\end{tabular}

We examined the associations between participants' some characteristics such as obesity risk perception, obesity risk awareness, the BMI percentile and eating behaviours scores (Table 2).

Table 2. Associations of obesity risk perception, obesity risk awareness, and BMI percentile levels with DEBQ Scores

\begin{tabular}{|c|c|c|c|}
\hline Characteristics & $\begin{array}{l}\text { Emotional eating } \\
\text { behaviour score }\end{array}$ & $\begin{array}{l}\text { External eating behaviour } \\
\text { score }\end{array}$ & $\begin{array}{c}\text { Restrained eating } \\
\text { behaviour } \\
\text { Score } \\
\end{array}$ \\
\hline & Mean (SD) & Mean (SD) & Mean (SD) \\
\hline $\begin{array}{c}\text { Obesity risk perception } \\
\text { Yes } \\
\text { No } \\
\end{array}$ & $\begin{array}{l}26.53(9.13) \\
23.49(8.43)\end{array}$ & $\begin{array}{l}32.27(15.95) \\
27.03(12.62)\end{array}$ & $\begin{array}{l}27.88(9.58) \\
26.73(7.83) \\
\end{array}$ \\
\hline $\mathrm{t}$; $\mathrm{p}$ values & $2.733 ; \mathbf{0 . 0 0 7}$ & $3.251 ; 0.001$ & $1.150 ; 0.251$ \\
\hline $\begin{array}{c}\text { Obesity risk awareness } \\
\text { Yes } \\
\text { No } \\
\end{array}$ & 24.68 (8.78) 23.43 (8.44) & 28.20 (14.31) 27.43 (12.53) & $26.80(8.37) 26.93$ (7.92) \\
\hline $\mathrm{t}$; $\mathrm{p}$ values & $1.672 ; 0.095$ & $0.673 ; 0.501$ & $0.182 ; 0.856$ \\
\hline $\begin{array}{l}\text { BMI persentile } \\
\text { Underweight } \\
\text { Normal } \\
\text { Overweight or obese }\end{array}$ & $\begin{array}{l}20.65(9.01) \\
24.33(8.51) \\
26.16(7.01) \\
\end{array}$ & $\begin{array}{l}26.80(12.59) \\
28.17(13.47) \\
26.37(12.50) \\
\end{array}$ & $\begin{array}{l}28.57(9.03) \\
26.78(7.77) \\
24.92(8.09) \\
\end{array}$ \\
\hline F; p values & $10.452 ;<\mathbf{0 . 0 0 1}$ & $0.831 ; 0.436$ & $4.280 ; \mathbf{0 . 0 1 4}$ \\
\hline
\end{tabular}

BMI, Body Mass Index.

Emotional eating behaviour score $(\mathrm{p}=0.007)$ and external eating behaviour score $(\mathrm{p}=0.001)$ of the adolescents who perceived themselves as having the risk of developing obesity were found to be higher than the group not perceiving any risk. Although emotional eating behaviour score and external eating behaviour score of those who were aware of some health problems caused by obesity were higher than those who were not aware of the health problems related to the obesity, this difference was not statistically significant ( $p>0.05)$. According to the BMI percentile, it was found that emotional eating behaviour score of the underweight adolescents was significantly lower than the adolescents in the other group $(\mathrm{p}<0.001)$. It was also observed that as the BMI percentile increased in the adolescents, emotional eating behaviour score increased. Similarly, there was a statistically significant difference among the restrained eating behaviour scores of underweight, normal and overweight or obese groups $(\mathrm{p}=0.014)$. Further analysis revealed that this was due to the difference between the overweight / obese group and the underweight group. In other words, restrained eating behaviour score of the overweight / obese adolescents was lower than the restrained eating behaviour score of the underweight adolescents. It was found that there was a very weak relationship among the health perception scores of the participants and emotional eating behaviour score $(p=0.003)$ and restrained eating behaviour score $(p=0.029)$, and there was also a weak relationship between the health perception scores and external eating behaviour score $(\mathrm{p}<0.001)$ (Table 3$)$. 
Table 3. Correlations between perception of health score and eating behaviour sub-scores of the participants (Pearson Correlation)

\begin{tabular}{|c|c|}
\hline Eating Behaviour Sub-scores & Perception of Health \\
\hline Emotional eating behaviour & $\mathrm{r}=0.124^{* *} ; \mathrm{p}=0.003$ \\
\hline External eating behaviour & $\mathrm{r}=-0.246^{* *} ; \mathrm{p}<0.001$ \\
\hline Restrained eating behaviour & $\mathrm{r}=-0.090^{*} ; \mathrm{p}=0.029$ \\
\hline
\end{tabular}

${ }^{*}$ Correlation is significant at the 0.05 level (2-tailed).

** Correlation is significant at the 0.01 level (2-tailed).

\section{Discussion}

It has been reported that obesity is on the rise and the trend cannot be explained only by genetic changes but also by environmental factors [16, 20]. Environmental factors can trigger obesity by affecting the nutrient intake of a person. Pressure from "obesogenic" environment increases obesity rates [21]. Eating behaviours of the social circle (family or peers) of individuals can affect the eating behaviours of the individual [22]. It has been reported that external eating is the predictor of the willingness to nutrient [23]. It was determined in our study that the adolescents were more inclined to the external eating behaviour despite their awareness of obesity risk. In other words, we found that the adolescents who believed they would develop obesity ate more depending on the images or smells in their surroundings (external eating) than the adolescents who believe they would not develop obesity. In this regard, it may be thought that the risk of developing obesity may also increase in the adolescents who indicated that their desire to eat increased due to environmental exposure.

Individuals may exhibit an excessive eating behaviour called "emotional eating behaviour" in response to emotional arousal or stress. In other words, they can use eating as a coping mechanism to reduce negative emotions [24, 25]. This study found that the adolescents who thought that they would develop obesity ate more when they were depressed, angry or anxious (emotional eating) than those who thought they would not develop obesity. The adolescents in our study group maintain their emotional eating behaviours even if they are aware that they may develop obesity or obesity may cause health problems. Despite their awareness, adolescents still do not change their eating habits. In other words, the self-consciousness of the adolescents alone does not seem sufficient for them to change their eating habits or behaviours. In this case, factors such as environmental influences and lifestyle behaviours of the family and social circle of the individuals can play a crucial role. For this reason, the effects of other variables related to emotional eating in the adolescents must be revealed, and in addition to dietary behaviour, interventions that focus on stress management need to be performed.

Adolescence is a fragile developmental stage sometimes characterised by exposure to stressful life events and by weakened mental health effects. It has been shown in the literature that there is a relationship among life stress and emotional symptoms and emotional eating behaviour [10,26]. Wilson et al. (2015) reported that the stress which the adolescents perceived affected their emotional eating behaviours [27]. Similarly to the findings in the literature, it can be said for our study that the risk of developing obesity is high in the adolescents who show emotional eating behaviour. In our study, the fact that the emotional eating behaviours scores of the overweight/obese adolescents are significantly higher than the healthy and underweight adolescents supports our prediction.

Restrained eating refers to how far away the individuals are from the food to be able to keep their body weight under control. The desire for nutrients is the most important factor in appetite control [28]. Fear of obesity can contribute to an individual showing more restrained eating behaviour to lose weight [26]. Previous studies showed that higher BMI in adolescents was associated with more restrained eating behaviour [24, 26]. Contrary to the previous studies, it was found in our study that overweight and obese adolescents had a lower restrained eating behaviour score than those who were underweight or had normal weight. Unlike the previous studies, the overweight and obese adolescents in our study group did not appear to have any restraint on the amount of food they eat. The reason why the overweight and obese adolescents in our study do not restrict eating may be related to the fact that they eat more food depending on the emotional influences.

The health beliefs, attitudes and perceptions of the individuals are among the factors affecting their health behaviour. A positive relationship between health perception and eating habits can be observed [29]. In one study, a strong positive correlation was found between health perception and healthy diet [30]. It was found in our study that there was a positive relationship between health perception score and emotional eating behaviour score. Based on this finding, it can be said that the positive health perception cannot limit the emotional eating behaviour. This finding shows that the adolescents eat more food due to the emotional influences. There was a negative relationship between health perception score and restrained eating behaviour score and external 
eating behaviour score of the adolescents in the study group. This finding shows that the adolescents with more positive health perception are less affected by the environment and they impose limitations on food selection. While planning the health education for the nutritional behaviours of the adolescents, it is important to be focused on improving their health perceptions as well as providing training on a healthy diet. Thus, it can be ensured that adolescents not only know what they should do but also why they should do so [29].

There were some limitations to this study. The first of these limitations is that this study was conducted with the adolescents studying in a high school in the centre of a city located in the west of Turkey. Adolescents who were not in high schools were not included in the study. The second limitation is that the age range (1417 years) of the adolescents participating in the study was rather narrow. For this reason, this study failed to represent the other adolescent ages. Another limitation of our study is that it is cross-sectional. Therefore, it was not possible to evaluate the change longitudinally in the eating behaviours of the adolescents. The fact that the emotional state of the adolescents was not questioned may have led to the failure to determine the relationship between emotional problems and eating behaviour.

\section{Conclusions}

The adolescents with better health perception are less affected by the environment, and they impose limitations on food selection. Overweight and obese adolescents tend to eat more depending on the emotional influences and environmental factors. Awareness of personal obesity risk as well as the causes of obesity and health risks of obesity do not positively affect the eating behaviours of the adolescents. We recommend that the relationship between the eating behaviours of the adolescents and the change in BMI percentile values should be evaluated in an observational cohort study from the beginning of adolescence to the end of the adolescence. Observation of the adolescents regarding their emotional eating behaviours and planning initiatives for stress control may be necessary in preventing obesity.

\section{Acknowledgements}

The authors thank the adolescents and their parents who agreed to participate in this study for their contribution. This study was published as a poster presentation at the $4^{\text {th }}$ PNAE Congress on Paediatric Nursing on 1 June 2018.

\section{References:}

1. Heymsfield SB, Wadden TA. Mechanisms, pathophysiology, and management of obesity. N Engl J Med. 2017; 376: 254-66. https://www.nejm.org/doi/10.1056/NEJMra1514009

2. World Health Organization. Adolescent obesity and related behaviours: trends and inequalities in the WHO European Region, 2002-2014 [Internet]. Copenhagen: World Health Organization; 2017 [cited 2018 May 05]. Available from: http://www.euro.who.int/_data/assets/pdf_file/0019/339211/WHO_ObesityReport_2017_ v3.pdf?ua=1

3. The European Association or the Study of Obesity (EASO). Obesity: an underestimated threat public perceptions of obesity in Europe [Internet]. 2015 [cited 2018 March 18]. Available from: http://easo.org/ perception-survey/

4. Maïano C, Hue O, Morin AJ, Moullec G. Prevalence of overweight and obesity among children and adolescents with intellectual disabilities: a systematic review and meta-analysis. Obes Rev. 2016; 17(7): 599-611. https://doi.org/10.1111/obr.12408

5. The NS, Suchindran C, North KE, Popkin BM, Gordon-Larsen P. Association of adolescent obesity with risk of severe obesity in adulthood. JAMA. 2010; 304(18): 2042-7. http://dx.doi.org/10.1001/jama.2010.1635

6. Al-Hazzaa HM, Abahussain NA, Al-Sobayel HI, Qahwaji DM, Alsulaiman NA, Musaiger AO. Prevalence of overweight, obesity, and abdominal obesity among urban Saudi adolescents: gender and regional variations. J Health Popul Nutr. 2014; 32(4): 634-45.

7. Velazquez CE, Pasch KE, Ranjit N, Mirchandani G, Hoelscher DM. Are adolescents' perceptions of dietary practices associated with their dietary behaviors?. J Am Diet Assoc. 2011; 111(11): 1735-40. https://doi.org/10.1016/j.jada.2011.08.003

8. Muturi NW, Kidd T, Khan T, Kattelmann K, Zies S, Lindshield E, et al. An examination of factors associated with self-efficacy for food choice and healthy eating among low-1ncome adolescents in three U.S. States. Front. Commun. 2016; 1: 6. https://doi.org/10.3389/fcomm.2016.00006 
9. Grzelak T, Dutkiewicz A, Paszynska E, Dmitrzak-Weglarz M, Slopien A, Tyszkiewicz-Nwafor M. Neurobiochemical and psychological factors influencing the eating behaviors and attitudes in anorexia nervosa. J Physiol Biochem. 2017; 73(2): 297-305. https://doi.org/10.1007/s13105-016-0540-2

10. Khodabakhsh M, Kiani F. Effects of emotional eating on eating behaviors disorder in students: the effects of anxious mood and emotion expression. Int J Pediatr. 2014; 2(4-1): 295-303. http://doi.org/10.22038/IJP.2014.3200

11. Michels N, Sioen I, Braet C, Eiben G, Hebestreit A, Huybrechts I, et al. Stress, emotional eating behaviour and dietary patterns in children. Appetite. 2012; 59(3): 762-9. http://doi.org/10.1016/j.appet.2012.08.010

12. Ramaiah RR. Prevalence of obesity and awareness of its risk factors among medical students of a rural teaching hospital of south India: a cross-sectional study. Int J Med Sci Public Health. 2015; 4(10): $1373-6$. http://doi.org/10.5455/ijmsph.2015.11012015283

13. Kansra P. Awareness of causes, consequences and preventive measures of obesity among adolescents in India. Munich Personal RePEc Archive. 2016; Paper No. 75475, 16-49.

14. Rosiek A, Maciejewska NF, Leksowski K, Rosiek-Kryszewska A, Leksowski Ł. Effect of television on obesity and excess of weight and consequences of health. Int J Environ Res Public Health. 2015; 12(8): 9408-26.

15. van Strien T, Frijters JER, Bergers GPA, Defares PB. The Dutch Eating Behavior Questionnaire (DEBQ) for assessment of restrained, emotional, and external eating behavior. Int J Eat Disord. 1986; 5: 295-315. https://doi.org/10.1002/1098-108X(198602)5:2<295::AID-EAT2260050209>3.0.C0;2-T

16. Bozan N, Bas M, Asci FH. Psychometric properties of Turkish version of Dutch Eating Behaviour Questionnaire (DEBQ). A preliminary results. Appetite. 2011; 56(3): 564-6. https://doi.org/10.1016/j.appet.2011.01.025

17. Diamond JJ, Becker JA, Arenson CA, Chambers CV, Rosenthal MP. Development of a scale to measure adults' perceptions of health: preliminary findings. J Community Psychol. 2007; 35(5): 557-61. https://doi.org/10.1002/jcop.20164

18. Kadığlu H, Yıldız A. [Validity and reliability of Turkish version of Perception of Health Scale]. Turkiye Klinikleri J Med Sci. 2012; 32(1): 47-53 (in Turkish). http://doi.org/10.5336/medsci.2010-21761

19. Neyzi O, Günöz H, Furman A, Günöz H, Furman A, Darendeliler F, et al. Weight, height, head circumference and Body Mass Index references for Turkish children. Çocuk Sağlığı Hast Derg. 2018; 51: 1-14. http://doi.org/10.4274/jcrpe.2183

20. Dar-Nimrod I, Cheung BY, Ruby MB, Heine SJ. Can merely learning about obesity genes affect eating behavior? Appetite. 2014; 81: 269-76. http://doi.org/10.1016/j.appet.2014.06.109

21. Carnell S, Wardle J. Appetite and adiposity in children: evidence for a behavioral susceptibility theory of obesity. Am J Clin Nutr. 2008; 88(1): 22-9. https://doi.org/10.1093/ajcn/88.1.22

22. Sharps M, Robinson E. Perceived eating norms and vegetable consumption in children. Int J Behav Nutr Phys Act. 2015; 14(12): 135. https://doi.org/10.1186/s12966-015-0296-z

23. Ferrer-Garcia M, Gutiérrez-Maldonado J, Pla-Sanjuanelo J, Vilalta-Abella F, Andreu-Gracia A, Dakanalis A, et al. External eating as a predictor of cuereactivity to food-related virtual environments. Stud Health Technol Inform. 2015; 219: 117-22. http://doi.org/10.3233/978-1-61499-595-1-117

24. Snoek HM, van Strien T, Janssens JM, Engels RC. Emotional, external, restrained eating and overweight in Dutch adolescents. Scand J Psychol. 2007; 48(1): 23-32. https://doi.org/10.1111/j.1467-9450.2006.00568.x

25. van Strien T, Cebolla A, Etchemendy E, Gutiérrez-Maldonado J, Ferrer-García M, Botella C, etal. Emotional eating and food intake after sadness and joy. Appetite. 2013; 66: 20-5. https://doi.org/10.1016/j.appet.2013.02.016

26. Hirsch O, Kluckner VJ, Brandt S, Moss A, Weck M, Florath I, et al. Restrained and external-emotional eating patterns in young overweight children-results of the Ulm Birth Cohort Study. PLoS ONE. 2014; 9(8): e105303. https://doi.org/10.1371/journal.pone.0105303

27. Wilson SM, Darling KE, Fahrenkamp AJ, D'Auria AL, Sato AF. Predictors of emotional eating during adolescents' transition to college: does Body Mass Index moderate the association between stress and emotional eating?. J Am Coll Health. 2015; 63(3): 163-70. https://doi.org/10.1080/07448481.2014.1003374

28. Snoek HM, Engels RC, van Strien T, Otten R. Emotional, external and restrained eating behaviour and BMI trajectories in adolescence. Appetite. 2013; 67: 81-7. https://doi.org/10.1016/j.appet.2013.03.014

29. Ichsan A, Afriandi I, Akhmad Gurnida D. Correlation between health perception, body image, and eating habits in high school students. AMJ. 2016; 3(2): 216-21. http://doi.org/10.15850/amj.v3n2.770

30. Korn L, Gonen E, Shaked Y, Golan M. Health perceptions, self and body image, physical activity and nutrition among undergraduate students in Israel. PLoS One. 2013; 8(3): e58543.

https://doi.org/10.1371/journal.pone.0058543 